tájrendezés témakörben, valamint a környezetvédelmi problémákról az állategészségügy területén. Tekintélyes helyet kapott a vitában a környezetvédelmi oktatás szerepe a gyakorlatban. Az egész problémakör interdiszciplináris jellege következtében fontosnak tartottuk, hogy a müszaki, vegyi és mezógazdasági tárgyak oktatásában meglévó együttmüködést is áttekintsük a felsớfokú környezetvédelmi képzésben.

Általános tapasztalat volt, hogy a felsóoktatásban még mindig nem vált egyöntetüen a szakképzés és a szakmai múveltség részévé a környezetvédelem. Vannak felsóoktatási intézmények hazánkban és más országokban is, ahol ez markánsabban kiforrott. Például a Szófiai Er. dészeti Múszaki Fóiskolán folyó ökológiai oktatás egyidejúleg diszciplináris és interdiszciplináris jéllegü. Az elsajátitandó tantárgyak nagy részének és az elméleti oktató-neveló, valamint a gyakorlati tevékenységnek szinte valamennyi formája ökológiai irányultságú, az erdógazdasági és erdótelepi tési karon szinte nincs olyan oktató-neveló és tudományos kutató tevékenység, amely nem függne össze a környezettel és amely a maga álláspontjából kiindulva nem lenne hasznára a tèrmészeti környezet védelmének és újjáteremtésének. Mindennek a módszertani és szakmai színvonala a bolgár értékelés szerint igen magas. Mindamellett az oktatási programba speciális tantárgyakat is felvettek a környezetvédelem tárgykörében; ezek önálló tantárgyak, specifikus kategóriákkal, törvényekkel, módszerekkel, az oktatás és az ökológiai ismeretek elsajátításának sajátos eszközeivel és formáival. E tárgyak alapján a bolgár Intézet már 1974 óta készít fel szakembereket „,a természeti környezet védelme" profillal.

Hasonlóan kedvezö tapasztalatokat a magyar erdészeti és agrár felsóoktatásban ugyancsak találunk, de a postgraduális képzést is ellátó müszaki és agráregyetemek kivételével sem hazánkban, sem más szocialista országban nem tekinthetjük megoldottnak e kérdést. Ezeket a gondokat is figyelembe vette a szakértői ülés, amikor a következó tudományos együttmüködési terv kialakításához javasolta, hogy a munkacsoport 1986-ban a Szovjetunióban vitassa meg a környezetvédelmi oktatás és nevelés helyzetét, jövőjét a társadalomtudományi oktatási intézményekben (a filozófia, jogi és újságírói szakon), 1987-ben pedig a múszaki tantárgyakban (építészeti, gépgyártás, elektronika stb.). Ezeket követóen pedig térjen vissza a mezógazdasági és erdészeti felsöoktatási intézményekben folyó környezetvédelmi oktatás és nevelés eredményeinek és újabb feladatainak megvitatására a KGST több oldalú tudományos együttmúködés keretében. Ez azt a felismerést igazolja, hogy a környezet- és természetvédelemre irányuló oktatás és nevelés, a lakosság ökológiai kultúrájának fokozása minden szférában egyre inkább az állami politika rangjára emelkedik hazánkban éppen úgy, mint a többi szocialista országban.

\title{
FODOR ISTVÁN
}

\section{SZEMELGETES EGY TANÁCSKOZÁS MUNKÁJÁBOL Szolnok, 1987. május 29-30.}

Kétnapos tudományos tanácskozásra került sor a megyeszékhelyen Urbanizáció - Lakótelep - Életmód címmel. A házigazda szerepét Szolnok Város Tanácsa és a Magyar Urbanisztikai Társaság együttesen töltötte be.

A konferencia módot kivánt nyújtani a cím sugallta problémák többoldalú megközelítésére, az urbanizáció egymástól elszakíthatatlan szociológiai és építészeti, valamint érintólegesen közigazgatási aspektusú vizsgálatára. Mindez köszönhetó volt a neves elóadók sorának, kiknek személyében az elmélet és a gyakorlat szakemberei egyaránt képviselve voltak. A téma idószerüsége a településfejlesztés jelenlegi helyzetével, körülményeivel támasztható alá, amikor szükség. 
szerü átgondolni többek között az életminöség ès az épitett környezet, a helyi önkormányzat - kapcsolódva a lakóhelyi demok ratizmushoz - szerepét.

A legfontosabb gondolatok kiemelése valamiféle vezérfonallá sürüsödik számunkra, de a megközelités elengedhetetlen feltétele a fennálló állapot elemzése a kritika éleslátásával:

- Az elmúlt évtizedek településpolitikájának egyoldalú, csak a negativumokra koncentráló birálata a jövöt illetóen tévútra vezet. Az eddigiekben azon nézet dominanciája érvén yesült, mely túlértékelte a településpolitikának a településfejlödésre vonatkozó jelentőségét, holott a fejlódésnek objektiv okai is voltak, illetve vannak, amelyek az apró- és kisfalvak fejlödését korlátozzák. Napjainkra azonban elmondható, hogy a településpolitika inkább szemléletet, mint tervet, koncepciót jelent. Összefüggésben azzal a trenddel, miszerint csökkent a generáción belüli foglalkozásváltás, a vándormozgalom, ugyanigy a helyi társadalmak fellazulása. Ennek következtében a lokalitás szerepe nött.

- Ez utóbbi tény nem csupán felszinen tartja, de meg is erösíti a valóságos önkormányzat létrehozásának igényét, melynek jogi garanciáit egy vonatkozásban hatályos Tanácstörvényünk már 1971 ben deklarálta. Megfogalmazást nyert a konferencián, hogy az önkormányzat feltétele a jelenlegi paradigmának egy újjal való felváltása. Azaz a delegált hatalom helyét a megosztott kom. petencia elve kell, hogy átvegye.

- A lakásügy, a lakásépités, söt a lakótelep kérdésköre képviselte mintegy a konkrétat az eszmecserén. Az elhangzottak szerint általában vett lakásügy nincsen, mivel az mindig az egyes állampolgár viszonya a létezó vagy nem létezó lakáshoz, s mindenkor az adott társadalom struktúrájához kell hozzárendelni a lakásstruktúrát. Lakáspolitikánk pedig nem azért rossz, mert panellakások épülnek. A kiemelt okok közül a lakótelepek betelepitésének esetlegessége súlypontozódott a lakóhelyi közösség, helyi társadalmi közösség kialakulásával, illetve ki nem alakulásával összefüggésben.

A továbbiakban - engedve a szerzó szubjektivitásának - az általam lényegesnek, a té. mát új gondolatokkal gazdagító eszmefuttatások kiragadására szorítkozom. Az elóadássorozato BELUSZKY PAL inditotta a településfejlödés és a településpolitika egymásra vonatkoztatott értékelésével. Az eddigiek tanúsága szerint egyolưalúan vizsgálták a településpolitika hatását a településfejlödésre. Figvelmen kivül maradtak a fejlödés objektiv okai, elsósorban apró- és kis. falvaink napjainkra elóállott helyzetét illetöen. BELUSZKY PÁL véleménye, hogy a település fejlödés a termelés, illetóleg a termelöerök térbeli elhelyezkedésének függvénye, mégpedig több tényezó figyelembevételével. A mezőgazdasági termelés ma már az üzemközpontokban összpon. tosul, ami a munkahely-kinálat mennyiségi és minöségi csökkenése révén hátrányosan és súlyosar érinti a kistelepüléseket. Ehhez kapcsolódik a közlekedés számukra változó lehetơsége, valamint a mobilitás, mely e falvakat sem kerülte el. Végül léteztek és léteznek az ERDEl FERENC álta csonka falunak nevezett települések. Összegzésként az állapítható meg, hogy az Országos Telepü léshálózat-fejlesztési koncepció - vitathatatlan pozitivumai, többek között a települési körülmé. nyek és más, addig nem vizsgált kérdések felvetése mellett - bár célrendszert adott, de ahhoz szükséges stratégiát és taktikát a legkevésbé. Koncentráit irányítási szisztéma kizárta a jogilag már biztosított önkormányzatiságot.

BÁNLAKY PÁL folytatva a gondolatmenetet "Önkormányzat a helyi társadalomban" címmel tartotta meg elóadását. Számára a vizsgálódás kiindulópontja a van, a jelen helyzet értelmezése. Mai valóságunk lényeges alapelve eszerint a központi hatalom omnipotenciájának téte. lezése, vagyis, hogy minden területen reális döntést képes hozni. Amikor ez utóbbi technikailag már nem kivitelezhetó, abban a pillanatban belép a rendezőelv, a delegált hatalom elve. Ennek értelmében a helyi társadalom nem rendelkezik saját hatáskörrel, tehát önkormányzatról is csupán korlátozott mértékben lehet szó. A felvázoltak szerint a megoldás az a váltás, mely a megosztott kompetencia elvében jelentkeznék, azon alapkérdéssel, hogy saját jogon bír hatáskörrel az önkormányzat, ami elvonhatatlan és beleszólási jog nélküli. BÁNLAKY PÁL szerint összefoglalva az eddigieket, a séma három sávra tagolódik. Az elsóbe a kizárólagos központi hatáskörbe tartozó döntések sorolódnak, a harmadikba a kizárólagos önkormányzati illetékesség. A második sáv további három rész re bomlik:

1. a központ dominanciáját mutató döntések,

2. az abszolút köztes rész mint az együttes döntések tere, végül a 
3.-at a helyi társadalom súlypontozza.

A helyi közösséget alkotó egyes ember mindennapjait befolyásoló lakásügy, lakáspolitika vitapontjait láttatta a résztvevökkel BERÉNYI ANDRÁS az építész szemszögéból. Elméleti bevezetőjében akként definiálta a lakásügyet, hogy az mindenkor konkrét, a mindenkori lakásstruktúra és az állampolgárok oldaláról megfogalmazódó igényszint egymáshoz való viszonya. Leszögezte, rossz a lakáspolitikánk, mellyel összefüggésben a lakótelepi lakásépítés ellentmondásaira figyelmeztetett. Többek között arra, hogy a lakótelep, mint lakókörnyezet elszakadás a történelmileg kialakult városi létformától. BERÉNYI ANDRÁS véleménye, hogy a lakásállománynak, illetve lakáspolitikának csak megoldáscentrikus alakításával érhetó el eredmény. A jövó útja, hogy nagyobb lakásokat építünk, tehát kevesebbet, de fajlagosan olcsóbbakat, aminek a meginduló cserefolyamat útján több ember gondját kell megoldania.

BÖHM ANTAL a regionális politika esélyeit választotta hozzászólása tárgyául, miközben azt a hatalmi struktúrában és az érdekek rendszerében kivánta elhelyezni. Mondandóját akként sommázta, hogy a regionális tervezés tulajdonképpen központi, csak regionálist mondunk. Ugyanakkor elkerülhetetlen a régiókban való gondolkodás, ha akárcsak ökológiai veszélyeztetettségünkre gondolunk.

A tanácskozás második napja a szekcióüléseknek szentelódött. A három szekció közül a BÁNLAKY PÁL vezette „Település-életmód" megnevezésúnek lehettem részese (mig a második szekciót "Település- és városkarakter" címmel KERÉNY! JÓZSEF, a harmadikat a „Lakásépítés - lakásgazdálkodás" témáját feldolgozót BEREY KATALIN irányította). Az elsóben POLGÁRNÉ TÁLL ÉVA tartott vitaindítót, attekintve a városfejlódés sok évszázados történetét, majd az urbanizáció folyamatát a vele együtt születó problémákkal.

A vita szálai elsősorban a lakótelep, mint modell, valamint az értelmiség közösségformáló ereje körül csomósodtak. A lakótelepet illetóen a hozzászólásokból az a kép rajzolódott ki, hogy a jelenlévő́k a lakótelepet szervetlen fejlödési modellként értelmezik. Elhelyezése mindenféle kötö́dést nélkülöz, véletlenszerü. A városhoz való kapcsolódása a közigazgatás szolgáltatta szálakra redukálódik. (KISSNÉ NOVÁK ÉVA) A lakótelepi életforma eléggé igénytelen, s sokszor terhes az ott lakók menekülési vágyával. A tény viszont, hogy kik élnek együtt, nemcsak a lakótelepeken, de bármely helyi társadalomban az értékek megóvása és a szolidaritás szempontiából meghatározó. (BELUSZKY PÁL)

Az érzelmek az agrárértelmiség közösségalakitó szerepe körül csaptak össze. Volt, aki a vidéki agrárértelmiség életmódjával, annak munkájából adódó rendszertelenségével magyarázta e réteg szerény aktivitását. (MÁTÉ TIBOR) Ellenvéleményként többek között az hangzott el, hogy míg a tudás általában elveszítette presztizsét, addig az agrárértelmiség növelte sajátját, azaz erjesztóje lehetne a helyi társadalomnak. (BÓHM ANTAL)

A kétnapos tanácskozás nem szolgáltathatott recepteket egyetlen megoldásra váró témában sem, de figyelemreméltó az a dialógus, amely a különbözర̋ szakmák képviselói között létrejött. Ha a helyszín okán is jut eszünkbe, igaz, hogy az OTK éppen az alföldi településhálózattól esett a legmesszebb. I tteni városaink a városfejlesztésben ma is bizonytalanok, mert örökségükkel szakitanak, amikor a dunántúli városok válnak mércéjükké. Továbbá kétségtelen tény. hogy a magyar városépités története, mint meghatározó gyökér Magyarországon még senki érdeklódését nem keltette fel stb. Mégsem kereshetünk felmentést az alól, hogy a jövő nemzedékei azon gondolat jegyében ítélkezzenek rólunk, miszerint „minden társadalom építészete a kor társadalma akaratának térbeli kifejeződése." A szükséges változtatásoknak azonban csak egyik vonatkozását adja a városépitészet. Nem tekinthetünk el attól, hogy a politikai rendszer egészébe ágyazottan egy sokkal demokratikusasbb, nyitottabb településpolitika jelenthet további utat számunkra. 